\title{
Levels of particulate matter in Western UAE desert and factors affecting their distribution
}

\author{
F. Al Jallad, E. Al Katheeri \& M. Al Omar \\ National Energy and Water Research Center (NEWRC), \\ Abu-Dhabi Water and Electricity Authority (ADWEA), UAE
}

\begin{abstract}
Levels of particulate matter and meteorological variables (atmospheric temperature, relative humidity and wind speed) for 2009 to 2011 were analyzed and evaluated. Data used in this paper were obtained from an ambient air quality station located in the western desert of Abu Dhabi Emirate-United Arab Emirates. The variation patterns of $\mathrm{PM}_{10}$ concentrations were explored, and their relationships with meteorological parameters were identified. The study area is characterized by relatively low wind speed, high temperatures and humidity and elevated levels of suspended particle concentrations. Hourly levels of $\mathrm{PM}_{10}$ were found to range between 4 to $3474 \mu \mathrm{g} / \mathrm{m}^{3}$ with $27 \%$ of the daily average values exceeding the national standard limit of $150 \mu \mathrm{g} / \mathrm{m}^{3}$. The diurnal variation pattern of $\mathrm{PM}_{10}$ showed two concentration peaks, the first of which occurred in the afternoon whereas the second peak occurred at 16:00. The highest level of $\mathrm{PM}_{10}$ was observed on Tuesdays, while the lowest level was on Fridays. The highest main value of $\mathrm{PM}_{10}$ was observed on July where a level of $204 \mu \mathrm{g} / \mathrm{m}^{3}$ was reported and lowest level of $47 \mu \mathrm{g} / \mathrm{m}^{3}$ was reported in January. Pearson's analysis revealed a positive correlation between $\mathrm{PM}_{10}$ and temperature, low humidity $(\leq 13 \%)$ and wind speed conditions. On the other hand, a strong inverse relationship was observed between $\mathrm{PM}_{10}$ concentrations and relative humidity higher than $13 \%$.

Keywords: particulate matter, meteorological parameters, Abu Dhabi, statistical analysis.
\end{abstract}

\section{Introduction}

Particulate matter (PM) may currently be considered as one of the most serious pollutants in urban areas, due to its harmful effects on human health and its role 
in climate change [1], in addition to ecosystem damage and degraded visibility [2]. PM is produced either from natural or anthropogenic sources. Natural PM includes material from the earth's crust, biological materials such as pollen and sea spray in coastal areas, whereas anthropogenic PM is directly emitted into the atmosphere or formed as a secondary pollutant when gaseous pollutants (e.g. $\mathrm{SO}_{2}, \mathrm{NO}_{\mathrm{x}}, \mathrm{NH}_{3}$ and VOCs) react to form fine particles [3]. Numerous studies have focused on variations in PM levels with respect to changes in meteorological parameters [2, 4-9]. Assuming the quantities of PM emitted from anthropogenic sources are constant in a certain season and area; therefore, the variations in PM levels can be partially attributed to the effects of meteorological conditions [5].

Wind speed, atmospheric temperature and relative humidity are thought to influence PM concentrations [10]. Stagnant wind conditions allow air pollutants to accumulate near Earth's surface, resulting in high localized concentrations of PM [11]. On the contrary, fast near surface winds are generally associated with high levels of particulate matter caused by resuspension of ground particles and long range transport of particulates between regions [2, 6]. Formation of secondary aerosols by gas to particle conversion is a temperature driven process in which atmospheric temperature plays a key role. Variations in the relative humidity have a clear effect on hygroscopic aerosol particle, where absorption of water increases the size of the individual particle and affect its lifetime in the atmosphere [12].

United Arab Emirates (UAE) has an arid climate. Winter seasons last from November through March, during which time temperatures seldom drop below $6^{\circ} \mathrm{C}$. Summers, which last from April through September, are very hot and humid, with temperatures rising to about $48^{\circ} \mathrm{C}$ and humidity levels higher than $90 \%$. Generally, winds are predominantly from the west and northwest with relatively low speed [13].

Abu Dhabi Emirate experiences elevated levels of air particles that are less than 10 micrometers in diameter $\left(\mathrm{PM}_{10}\right)$ [14]. The high concentrations of $\mathrm{PM}_{10}$ are generally caused by natural sources such as windblown desert sand and sea spray [15]. In this study, three years data (2009-2011) describing ambient $\mathrm{PM}_{10}$ concentrations, atmospheric temperature, relative humidity and wind speed were analyzed and evaluated for the western desert of Abu Dhabi Emirate, UAE. PM 10 ambient levels, temporal variations and correlations with meteorological variables were determined.

\section{Methodology}

\subsection{Study area}

Western Region constitutes the western part of Abu Dhabi Emirate. It represents around $80 \%$ of the total Emirate area. Jabal Al Dhanna is a coastal area located in the western region at approximately $235 \mathrm{~km}$ west of Abu Dhabi city (Figure 1). An ambient air quality monitoring station is installed in this area which will be 


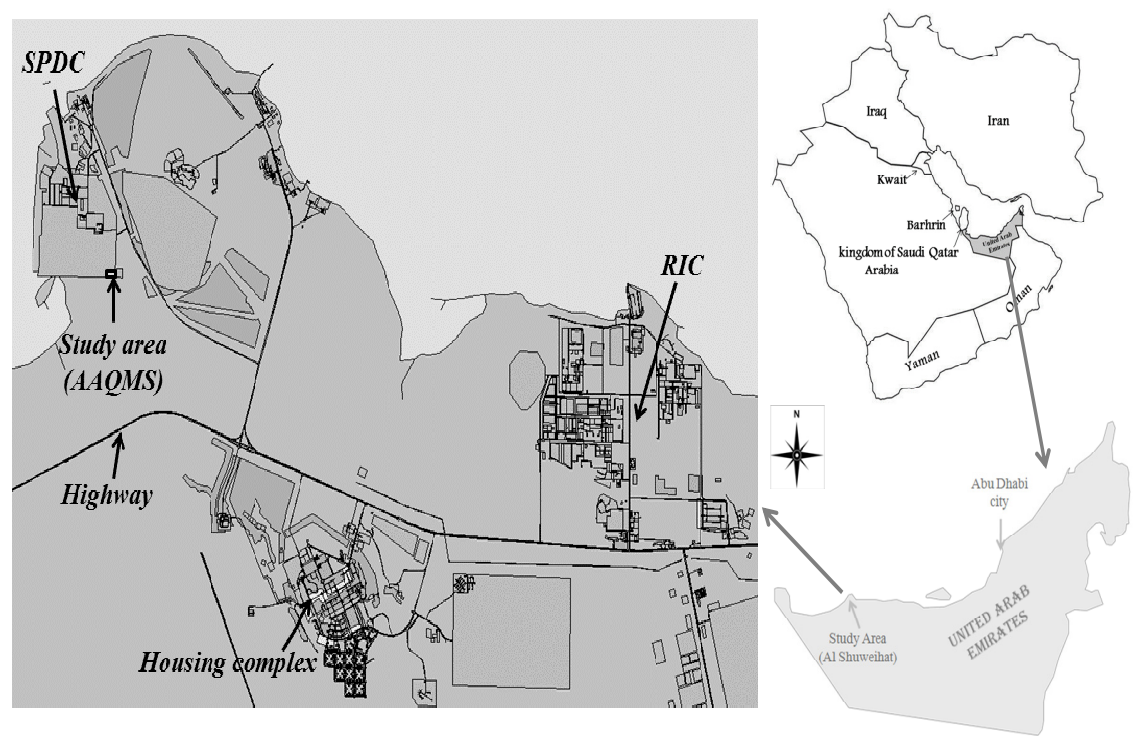

Figure 1: $\quad$ Map of United Arab Emirates showing the study area at the western region.

referred to as "the study area". The main anthropogenic air pollution sources in the area are as follows:

Shuweihat Power and Desalination Complex (SPDC): Located approximately $2 \mathrm{~km}$ northwest (upwind) of the study area, this complex consists of power and desalination facilities powered primarily by natural gas, although heavy fuel oil and diesel are also used occasionally [16]. The data used in this study was obtained from an ambient air quality monitoring (AAQM) station located in the south-eastern corner of this Complex. The latitude and longitude of the monitoring station are $24^{\circ} 8^{\prime} 55.93^{\prime \prime} \mathrm{N}$ and 52 $35^{\prime} 2.51^{\prime \prime} \mathrm{E}$, respectively.

Ruwais industrial Complex (RIC): Located approximately $8 \mathrm{~km}$ southeast of the study area. The complex encompasses three main industrial activities, oil refinery, polymer production and natural gas industry.

Transportation emissions: In addition to transportation of material and public, main highway is located at approximately $3 \mathrm{~km}$ south of the study area. The traffic movement may be described as mild with mostly light vehicles and trucks.

Population of the entire western area surrounding Jabal Al Dhanna and its vicinities is rather limited and does not exceed seventeen thousands according to recent census [17]. Ruwais Housing Complex is the most densely populated part in the study area; it is located at about $8 \mathrm{~km}$ to the south-east of the monitoring station and consists of about 1300 units and houses. As far as natural sources of dust are concerned, the area is part of the desert region with no vegetation cover; however, soil is composed of coarse sand particles. Nevertheless, fine sand particles can also be found as a result of off road movement of vehicles in addition to construction. 


\subsection{Air quality monitoring instrument}

Data used in this paper were obtained from the Al Shuweihat AAQM station. The station is owned and operated by the National Energy and Water Research Center (NEWRC) on behalf of the Abu Dhabi Water and Electricity Authority (ADWEA). Suspended particle concentrations were monitored on hourly basis using a beta attenuation dust monitor (Environment S.A., France, model MP101M) equipped with a $\mathrm{PM}_{10}$ size selective inlet mounted $3 \mathrm{~m}$ above ground level and operated with a full scale measurement range of $5000 \mu \mathrm{g} / \mathrm{m}^{3}$. The sample flow rate is automatically regulated at $1 \mathrm{~m}^{3} / \mathrm{hr}$, and the sampling probe is heated to $50^{\circ} \mathrm{C}$ to prevent moisture condensation.

A wind speed sensor (LSI-LASTEM, Italy, model DNA021) and thermohygrometer (LSI-LASTEM, Italy, model DMA685) are mounted at $10 \mathrm{~m}$ mast in the same monitoring station. The meteorological data are originally retrieved on five minute intervals. For calculation of the hourly averages, a minimum of $75 \%$ of the hour's records must be available; otherwise the value is considered as missing.

\section{Results and discussion}

The average concentrations of $\mathrm{PM}_{10}$ were calculated at different observations of the meteorological parameters to investigate their relationships using Pearson's correlation analysis [18]. The recommended guideline value of $\mathrm{PM}_{10}$ in $\mathrm{Abu}$ Dhabi Emirate is set as $150 \mu \mathrm{g} / \mathrm{m}^{3}$ according to the national ambient air quality standard [1].

During the study period, a total of 24,359 valid hourly $\mathrm{PM}_{10}$ values were obtained from the monitoring station. Meteorological data that had been simultaneously recorded was also collected. Temporal variation of the $\mathrm{PM}_{10}$ concentrations and meteorological variables were analyzed, and their relationships were identified.

Monthly average values along with standard deviation for the meteorological parameters are presented in Table 1. The maximum values for wind speed (WS), relative humidity $(\mathrm{RH})$ and temperature were observed in March, December and August, respectively. Monthly mean values during the study period was found to be $4.2 \mathrm{~m} / \mathrm{sec}$ for wind speed, $62 \%$ for relative humidity and $27.3^{\circ} \mathrm{C}$ for atmospheric temperature. These findings indicate that the study area is characterized by relatively low wind speed and high temperatures and humidity. Hourly values of $\mathrm{PM}_{10}$ during the study period ranged from $4 \mu \mathrm{g} / \mathrm{m}^{3}$ to $3474 \mu \mathrm{g} / \mathrm{m}^{3}$, with a mean value of $128 \mu \mathrm{g} / \mathrm{m}^{3}$. The $98^{\text {th }}$ percentile of $\mathrm{PM}_{10}$ observations was less than $623 \mu \mathrm{g} / \mathrm{m}^{3}$, which is less than one fifth of the maximum monitored value. Daily mass concentrations of $\mathrm{PM}_{10}$ ranged from 14 to $1188 \mu \mathrm{g} / \mathrm{m}^{3}$ (Figure 2). About $27 \%$ of the daily average concentrations exceeded the limit of $150 \mu \mathrm{g} / \mathrm{m}^{3}$ stated in the national air quality standard. 
Table 1: $\quad$ Monthly average values of some meteorological parameters (wind speed, relative humidity and temperature) in the study area for the years 2009-2011.

\begin{tabular}{|lccc|}
\hline Month & $\begin{array}{c}\text { WS } \pm \text { S.D } \\
(\mathrm{m} / \mathrm{s})\end{array}$ & $\begin{array}{c}\text { RH } \pm \text { S.D } \\
(\%)\end{array}$ & $\begin{array}{c}\text { Temp. } \pm \text { S.D } \\
\left({ }^{\circ} \mathrm{C}\right)\end{array}$ \\
\hline January & $3.8 \pm 2.5$ & $67.3 \pm 21.1$ & $17.8 \pm 4.3$ \\
\hline February & $4.7 \pm 2.1$ & $56.8 \pm 23.3$ & $19.9 \pm 3.1$ \\
\hline March & $5.1 \pm 2.4$ & $55.0 \pm 19.1$ & $22.7 \pm 3.0$ \\
\hline April & $4.9 \pm 2.7$ & $51.5 \pm 20.1$ & $27.0 \pm 4.3$ \\
\hline May & $4.5 \pm 2.5$ & $48.8 \pm 13.6$ & $31.3 \pm 3.3$ \\
\hline June & $4.2 \pm 2.4$ & $55.5 \pm 22.5$ & $33.1 \pm 3.4$ \\
\hline July & $4.2 \pm 2.6$ & $58.6 \pm 23.5$ & $34.1 \pm 3.7$ \\
\hline August & $3.9 \pm 2.7$ & $66.8 \pm 20.0$ & $34.4 \pm 4.1$ \\
\hline September & $3.6 \pm 2.5$ & $68.8 \pm 22.2$ & $32.2 \pm 3.9$ \\
\hline October & $3.4 \pm 2.1$ & $71.0 \pm 21.1$ & $28.9 \pm 3.6$ \\
\hline November & $3.8 \pm 2.1$ & $67.6 \pm 21.2$ & $24.9 \pm 3.4$ \\
\hline December & $4.1 \pm 2.1$ & $74.1 \pm 21.0$ & $20.1 \pm 3.0$ \\
\hline Annual & $4.2 \pm 2.5$ & $61.8 \pm 22.4$ & $27.3 \pm 6.8$ \\
\hline
\end{tabular}

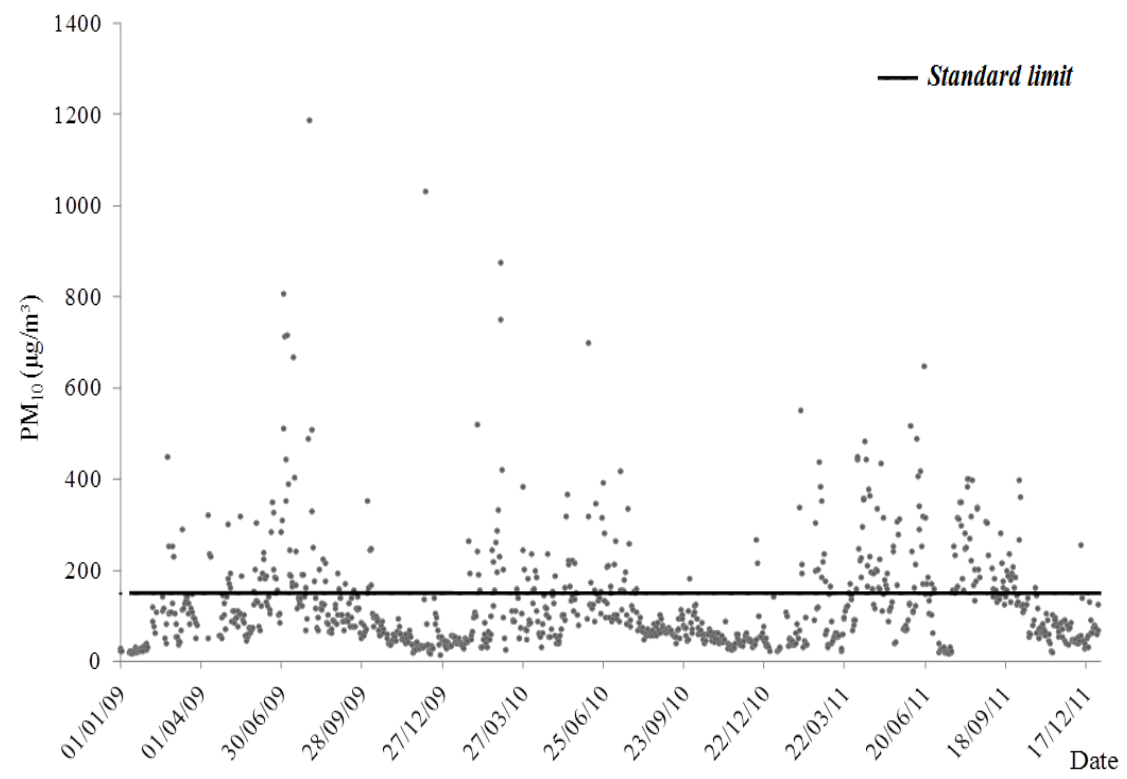

Figure 2: A dispersion diagram of the daily average concentrations of $\mathrm{PM}_{10}$ in air.

The diurnal variation pattern of $\mathrm{PM}_{10}$ mass concentrations during the study period is shown in Figure 3. The minimum average value was found to occur at 07:00. On the contrary, two peaks concentrations were observed for $\mathrm{PM}_{10}$, the primary peak occurred during the afternoon and the secondary peak occurred at 
16:00. The diurnal variation of $\mathrm{PM}_{10}$ is compared with the meteorological variation pattern in Figure 4, concluding that the lowest concentrations of $113 \mu \mathrm{g} / \mathrm{m}^{3}$ coincided with high humidity $(71 \%)$ and relatively low wind speed $(3.1 \mathrm{~m} / \mathrm{sec})$ and atmospheric temperature $\left(23.9^{\circ} \mathrm{C}\right)$, while the peak concentrations of $148 \mu \mathrm{g} / \mathrm{m}^{3}$ coincided with low humidity $(49 \%)$ and relatively high wind speed $(6.0 \mathrm{~m} / \mathrm{sec})$ and atmospheric temperature $\left(30.6^{\circ} \mathrm{C}\right)$.

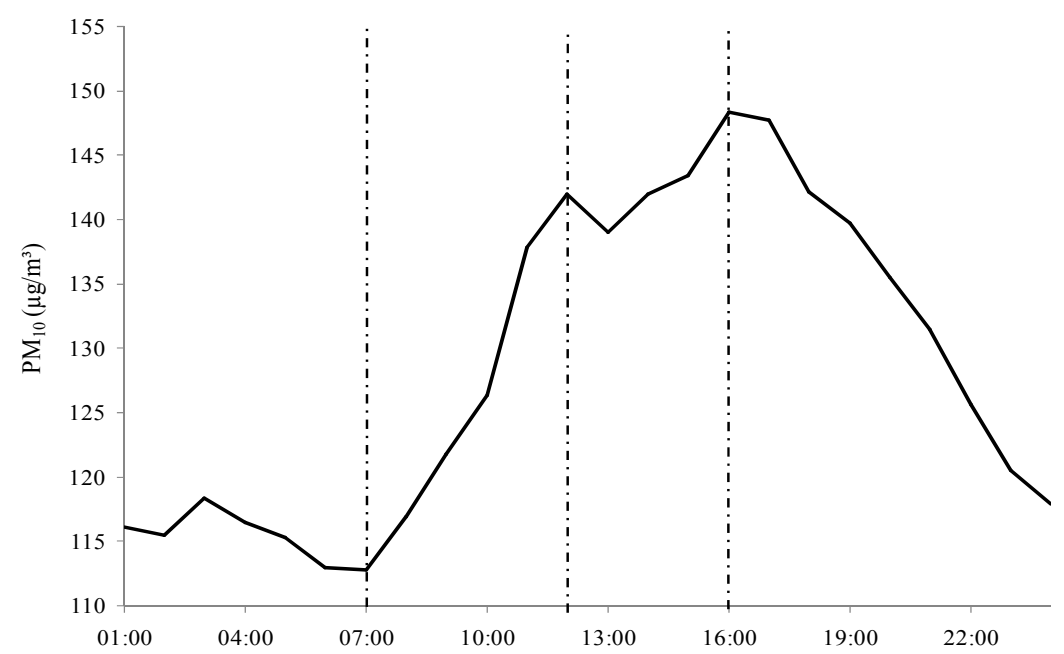

Figure 3: Diurnal variation pattern of $\mathrm{PM}_{10}$ at the study area for the period 2009-2011.

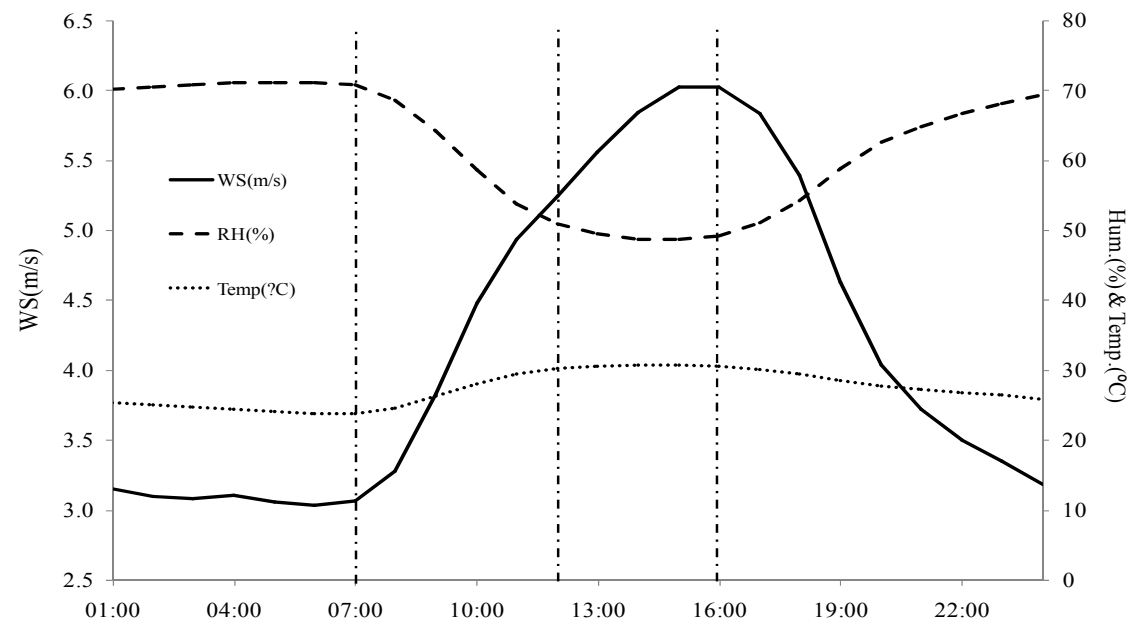

Figure 4: Diurnal variations of meteorological variables at the study area for the period 2009-2011. 
Data analysis for $\mathrm{PM}_{10}$ concentrations revealed that the highest mean concentration of $130 \mu \mathrm{g} / \mathrm{m}^{3}$ found to occur on Tuesdays, whereas the lowest value of $125 \mu \mathrm{g} / \mathrm{m}^{3}$ was recorded on Fridays (Figure 5); this finding may be attributed to less public activities in the weekends.

Monthly and seasonal variations of $\mathrm{PM}_{10}$ during the study period were not consistent as can be seen in Figure 6. The highest monthly average value was $319 \mu \mathrm{g} / \mathrm{m}^{3}$ recorded in July 2009 , while the lowest average value of $24 \mu \mathrm{g} / \mathrm{m}^{3}$ was

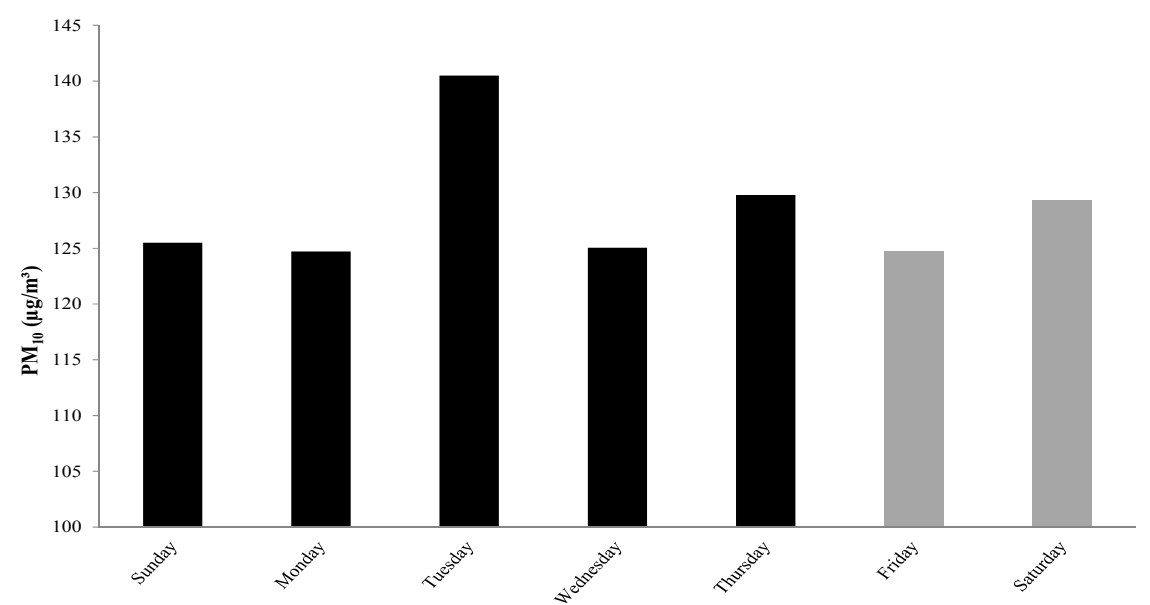

Figure 5: Weekdays/weekends variation of $\mathrm{PM}_{10}$.

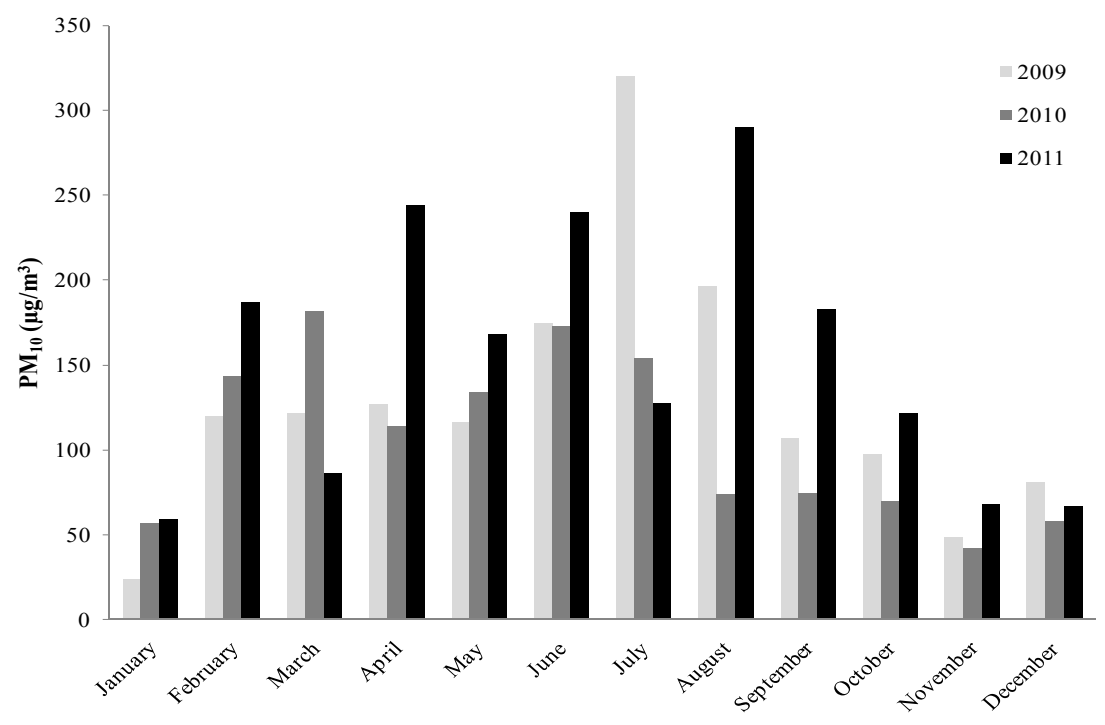

Figure 6: Seasonal variation of PM10 during 2009 to 2011. 
observed in January 2009. Table 2 includes statistical analysis for $\mathrm{PM}_{10}$ daily average values during the study period. The maximum daily mean value was found to be $1188 \mu \mathrm{g} / \mathrm{m}^{3}$ and recorded on 08 January 2009. The highest annual mean value of $148 \mu \mathrm{g} / \mathrm{m}^{3}$ was calculated for the year 2011 .

Table 2: $\quad$ Minimum, maximum and mean annual values of $\mathrm{PM}_{10}$ in the study area.

\begin{tabular}{|ccccc|}
\hline Year & $\begin{array}{c}\text { No. valid } \\
\text { observations }\end{array}$ & \multicolumn{2}{c|}{ Concentrations of $\mathrm{PM}_{10}$ in air $\left(\mu \mathrm{g} / \mathrm{m}^{3}\right)$} \\
Minimum & Maximum & Mean \pm S.D \\
\hline 2009 & 323 & 14 & 1188 & $125 \pm 135$ \\
\hline 2010 & 341 & 23 & 875 & $106 \pm 100$ \\
\hline 2011 & 323 & 17 & 646 & $148 \pm 114$ \\
\hline
\end{tabular}

The relationships between suspended particle concentrations and meteorological variables (wind speed, relative humidity and ambient temperature) were investigated using Pearson's correlation analysis, the analysis results are shown in Table 3 and Figure 7. A strong positive correlation was found between $\mathrm{PM}_{10}$ and the atmospheric temperature $(\mathrm{r}=0.87)$. This correlation can be explained by the effects of temperature on formation of new particles through gas to particle conversion processes. The effect of atmospheric temperature on $\mathrm{PM}_{10}$ levels is very obvious in the seasonal variation pattern of $\mathrm{PM}_{10}$.

High humidity conditions $(>13 \%)$ are inversely correlated with $\mathrm{PM}_{10}$ concentrations, as indicated by the moderate negative coefficient $(\mathrm{r}=-0.58)$. This correlation might be attributed to the effects of air moisture on coalescence

Table 3: Correlations of between $\mathrm{PM}_{10}$ and different meteorological parameters in the study area during 2009 to 2011.

\begin{tabular}{|lccc|}
\hline Parameter & Criteria & $\begin{array}{c}\text { Pearson } \\
\text { Correlation } \\
\text { Coefficient }(r)\end{array}$ & $\begin{array}{c}\text { Coefficient of } \\
\text { Determination } \\
\left(R^{2}\right)\end{array}$ \\
\hline \multirow{2}{*}{ Temperature $\left({ }^{\circ} \mathrm{C}\right)$} & All observations & 0.87 & 0.76 \\
& $\leq 37$ & 0.99 & 0.97 \\
\cline { 2 - 4 } Relative Humidity $(\%)$ & $>37$ & 0.80 & 0.64 \\
& All observations & -0.20 & 0.04 \\
\hline \multirow{2}{*}{ Wind speed $(\mathrm{m} / \mathrm{sec})$} & $\leq 13$ & 0.87 & 0.75 \\
& $>13$ & -0.58 & 0.33 \\
& All observations & 0.64 & 0.42 \\
\hline & $<10$ & 0.80 & 0.64 \\
\hline
\end{tabular}




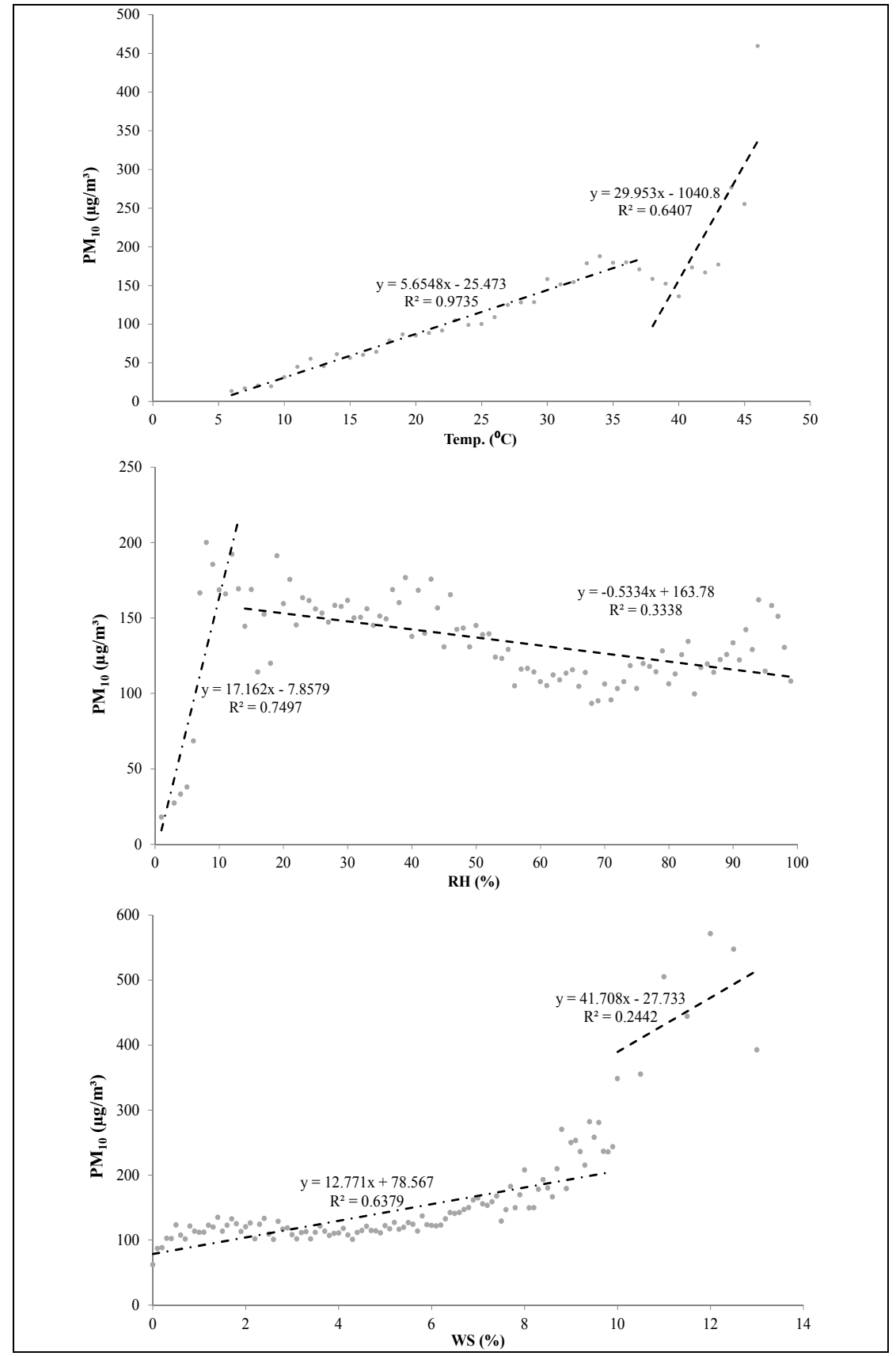

Figure 7: Linear regression between suspended particles and meteorological variables (temperature, relative humidity and wind speed). 
and settling of suspended particles from the atmosphere. Conversely, dry conditions $\left(\leq 13 \%\right.$ relative humidity) are strongly correlated with $\mathrm{PM}_{10}(\mathrm{r}=0.87)$, which may be attributed to the effects of humidity on coagulation and propagation of ultrafine particles. Finally, a moderate positive correlation was observed between wind speed and $\mathrm{PM}_{10}(\mathrm{r}=0.64)$ due to the re-suspension effect of wind and the potential of winds to transport particulates between regions around the study area. However, strong correlation $(r=0.80)$ was observed for the wind speed s lower than $10 \mathrm{~m} / \mathrm{sec}$, where the more observations can be found and correlated.

\section{Conclusion}

Based on the analyses of $\mathrm{PM}_{10}$ and their correlation with meteorological parameters, the following conclusions can be reached:

- The study area is characterized by relatively low wind speed and high temperatures and humidity.

- Elevated levels of suspended particles were observed in the study area, where $27 \%$ of the daily average values exceeded the national standard limit of $150 \mu \mathrm{g} / \mathrm{m}^{3}$.

- The diurnal variation pattern of $\mathrm{PM}_{10}$ levels showed two concentration peaks, the primary peak occurred during the afternoon and the secondary peak occurred at 16:00. Seasonal variations in $\mathrm{PM}_{10}$ did not follow a similar pattern during the study period. However, dry seasons showed a higher level of $\mathrm{PM}_{10}$, while the lowest concentrations were recorded in the wet seasons. Tuesdays showed higher concentrations of $\mathrm{PM}_{10}$, while the lowest level was found to be on Fridays (weekend).

- Pearson's analysis showed that there is positive correlation between the ambient $\mathrm{PM}_{10}$ level and each of atmospheric temperature, wind speed and low humidity conditions. Conversely, there is a strong inverse correlation between $\mathrm{PM}_{10}$ and relative humidity levels greater than $13 \%$.

\section{Acknowledgements}

The authors are thankful to Eng. Khaled Al Ameri/Head of the Technical Support Section at the National Energy \& Water Research Center (NEWRC) for his cooperation and to Eng. Santosh K.L. for his efforts to maintain AAQM instruments during the study period.

\section{References}

[1] Hueglin, C., Gehrig, R., Baltensperger, U., Gysel, M., Monn, C., and Vonmont, $\mathrm{H}$, Chemical characterization of $\mathrm{PM}_{2.5}, \mathrm{PM}_{10}$ and coarse particles at urban, near-city and rural sites in Switzerland. Atmospheric Environment, 39(4), pp. 637-651, 2005. 
[2] Wise, E. K., and Comrie, A. C., Meteorologically adjusted urban air quality trends in the southwestern United States. Atmospheric Environment, 39: 2969-2980, 2005.

[3] United States Environmental Protection Agency (US-EPA), Guidelines for developing an air quality (ozone and $\mathrm{PM}_{2.5}$ ) forecasting program, EPA456/R-03-002, pp. 1-2, 2003.

[4] Hien, P. D., Bac, V. T., Tham, H. C., Nhan, D. D., and Vinh, L. D., Influence of meteorological conditions on $\mathrm{PM}_{2.5}$ and $\mathrm{PM}_{2.5-10}$ concentrations during the monsoon season in Hanoi, Vietnam. Atmospheric Environment, 36, pp. 3473-3484, 2002.

[5] Giri, D., Krishna, M. V., and Adhikary, P. R., The influence of meteorological conditions on $\mathrm{PM}_{10}$ concentrations in Kathmandu Valley. International Journal for Environmental Research, 2(1), pp. 49-60, 2008.

[6] Gietl, J. K., and Klemm, O., Analysis of traffic and meteorology on airborne particulate matter in Münster, northwest Germany. Air and Waste Management Association, 59 (7), pp. 809-818, 2009.

[7] Akyuz M., and Çabuk, H., Meteorological variations of $\mathrm{PM}_{2.5} / \mathrm{PM}_{10}$ concentrations and particle-associated polycyclic aromatic hydrocarbons in the atmospheric environment of Zonguldak, Turkey. Journal of Hazardous Materials, 170(1), pp. 13-21, 2009.

[8] Galindo, N., Varea, M., Gil-Molto, J., Yubero, E., and Nicolas, J., The influence of meteorology on particulate matter concentrations at an urban Mediterranean location. Water, Air, and Soil Pollution, 215, pp. 365-372, 2010.

[9] Bhaskar, B. V., and Mehta, V. M., Atmospheric particulate pollutants and their relationship with meteorology in Ahmedabad. Aerosol Air Quality Research, 10, pp. 301-315, 2010.

[10] Gebhart, K. G., Kreidenweis, S. M., and Malm, W. C., Back trajectory analyses of fine particulate matter measured at Big Bend National Park in the historical database and the 1996 scoping study. Science of the Total Environment, 276, pp. 185-204, 2001.

[11] Chaloulakou, A., Kassomenos, P., Spyrellis, N., Demokritou, P., and Koutrakis, $\mathrm{P}$., Measurements of $\mathrm{PM}_{10}$ and $\mathrm{PM}_{2.5}$ particle concentrations in Athens, Greece. Atmospheric Environment, 37, pp. 649-660, 2003.

[12] Nilsson, B. A., Model of the relation between aerosol extinction and meteorological parameters. Atmospheric Environment, 28(5), pp. 815-825, 1994.

[13] Initial National Communication to the United Nations Framework Convention on Climate Change. Ministry of Energy (MoE), UAE, 2006, pp. 14-15.

[14] Annual Bulletin of Climate and Air Statistics. Statistics Centre of Abu Dhabi (SCAD), Abu Dhabi Emirate, UAE, 2010, pp. 14-23.

[15] Al-Aidrous, F., Madi, M. T., and Bener, A., Air quality in Abu-Dhabi and health effect. A paper presented at the $4^{\text {th }}$ Annual UAE University Research Conference, held in Al Ain, UAE on April, 2003. 
[16] Waste and pollution sources of Abu Dhabi Emirate, State of Environment, Environment Agency of Abu Dhabi (EAD), Abu Dhabi Emirate, UAE, pp. 71-91, 2008.

[17] Personal communication, May 2007, Statistician, Ministry of Economy, Abu Dhabi, UAE.

[18] Peck, R., Olsen, C., and Devore, J., Introduction to Statistics and Data Analysis, $4^{\text {th }}$ edition. Belmont, CA: Thomson Brooks/Cole, 2011, pp. 742752.

[19] Regulation Concerning Protection of Air from Pollution, Council of Ministers, Decree No. (12), 2006, Annex \#8, Ambient Air Quality Standards, Air Pollutants Limits in the Ambient Air, p. 61. 